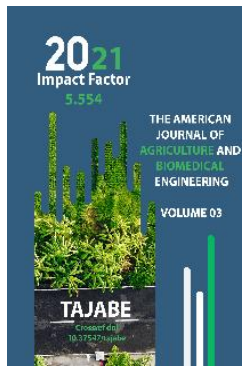

Journal Website: http://theamericanjour nals.com/index.php/taj abe

Copyright: Original content from this work may be used under the terms of the creative commons attributes 4.0 licence.

\section{Determination Of Effective Parasite-Entomofag Species In The Management Of The Number Of Family Representatives In Pieridae}

\author{
X.X.Kimsanbaev \\ Professor, Tashkent State Agrarian University, Uzbekistan
}

R.A.Jumaev

Professor, Tashkent State Agrarian University, Uzbekistan

L.A.Abduvosiqova

Associate, Tashkent State Agrarian University, Uzbekistan

\title{
ABSTRACT
}

The article covers studies that cabbage white butterfly is considered a dangerous pest common in vegetable crops and can cause great harm by feeding on more than 10 species of cabbage crops. Also, such pests as cabbage white butterfly, turnip white butterfly and rap white butterfly have been covered in scientific research to prevent the death of up to $60-65 \%$ of the crop in cabbage, turnip, radish and radish crops in mammal conditions.

\section{KEYWORDS}

Pieris brassicae, Pieris rapae, Synchloe daplidice, Mamestra brassicae, Agrotis segetum, Agrotis exclamationis, Autographa gamma.

\section{INTRODUCTION}

It is known to our barge that one of the types of vegetable crops, in which the morality of our country grows year after year, is a kind of cabbage crop. Cabbage is desirable to fall in love with the Tamon of the inhabitants of the country in different views on four seasons. In biosenosis, more than 10 different pests of cabbage crop are encountered, the main part of which is made up of representatives of the Lepidoptera category. Many of the family representatives of the cabbage crop mainly white butterflies (Pieris brassisae, Pieris rapae, Synchloe daplidise), tugs (Plutella masulipennis) and tonsils (Mamestra brassisae, Agrotis segetum, Agrotis exslamationis, Autographa gamma) have 
brought as is known in detail in the results of the above studies.

Purpose of the study: in order for the research to be clear and understandable, we aimed to carry out scientific research on 3 main family pests encountered in cabbage agrobiocenosis of Lepidoptera category in alokhi-alokhi. This research work was devoted to the identification and biolaboratorization of effective species of parasitic homophage in the Pieridae, Plutellidae and Nostuidae families.

\section{RESEARCH MATERIALS}

The number of Representatives of Lepidoptera category in the observations conducted in the cabbage agrobiocenosis of Tashkent and Syrdarya regions of the Republic was very large, and their diversity was studied. According to our collected data, the main parasite-boss species composition of pests encountered in biosenosis and their nutritional specialization were determined.

Scientific experiments conducted in accordance with the results of scientific research conducted by scientists from our country, Rassia and Kazakhstan, their data confirmed our results, including the detection of about 30 parasites and predatory species of the main 5 pests of the Lepidoptera category, which are found in cabbage agrobiocenosis in Central Asia, it was studied that the number of these pests

In our research, more than 15 species of parasites of Lepidoptera pests encountered in cabbage crop in Uzbekistan were identified as a result of scientific research.

\section{RESULTS}

The first part of our research work was carried out in order to identify and account for the types of parasite-entomophage in the effective management of the number of Representatives of the Pieridae family (Pieris brassicae, Pieris rapae, Synchloe daplidice), which are among the main pests of the Lepidoptera category, which are very common in cabbage agrobiocenosis.

In the case of a sharp increase in the season period of pests, it is recommended to use a large number of chemical preparations to reduce its number, but as a result, the biological balance in agrobiocenosis is disturbed, with a short period of time the number of pests increases even more. On the other side, as a result of the use of a drug of a homogeneous type on the larynx, the pest creates resistance to them. This causes an increase in the processing volume, repeatability, consumption norm of pesticides every year against pests.

The main goal of our research is to provide the population of our country with environmentally friendly agricultural products. This research work is aimed at solving exactly this problem. In this regard, we mowed down the dashing experiences.

Another observation conducted on the parasitism entomophages of the white cabbage butterfly has reduced the number of pests encountered by Apanteles plutellae, Apanteles Cossack and Apanteles glomeratus parasite species in its small and large age worms to $65 \%$. 
The American Journal of Agriculture and Boimedical Engineering (ISSN - 2689-1018)

According to research conducted on parasiticpredatory entomophages encountered in cabbage agrobiocenosis in 2018-2021 years in the conditions of Tashkent region, $69.5 \%$ of the total entomophages content was determined to consist of parasites.

According to him, according to the results of the research carried out to determine the species composition of parasites of the
Pieridae family, representatives of the Tashkent region's cabbage agrobiocenosis, 12 types of parasites of the trichogrammatidae, Braconidae and Pteromalidae entomofag families belonging to the 5 family of the Hymenoptera category were detected in the cabbage agrobiocenosis. It became known that the representatives of the Tachinidae family of the Diptera category met 2 Type.

1-Table

Parasitism entomofag species composition of pests of the Pieridae family, which suffer from Cabbage agrobiocenosis. ("Islam Dilorom agrofayz" F/x, 2017-2019 yy, lower Chirchiq District of Tashkent region).

\begin{tabular}{|c|c|c|c|}
\hline № & Types of parasites & $\begin{array}{l}\text { Pest } \\
\text { Type }\end{array}$ & Nutrition specialization \\
\hline 1 & Trichogrammatidae family & Order of the coins & Descendants \\
\hline 1.1 & Trichogramma evanescens Westv & $-\|-$ & $-\|-$ \\
\hline 1.2 & Trichogramma pintoi Voeg & $-\|-$ & $-11-$ \\
\hline 1.3 & Trichogramma chilonis Ichii & $-\|-$ & $-11-$ \\
\hline 1.4 & Trichogramma ostriniae Wang & $-\|-$ & $-\|-$ \\
\hline 2 & Braconidae family & Order of the tangenziae, & Buds \\
\hline 2.1 & Apanteles plutellae Kurd & $-\|-$ & $-\|-$ \\
\hline 2.2 & Apanteles telengai Tobias & $-\|-$ & $-\|-$ \\
\hline 2.3 & Apanteles kazak Tel & $-\|-$ & $-\|-$ \\
\hline 2.4 & Apanteles glomeratus L & $-\|-$ & $-\|-$ \\
\hline 2.5 & Cotesia glomerata L & $-\|-$ & $-\|-$ \\
\hline 2.6 & Bracon hebetor Say & $-\|-$ & $-\|-$ \\
\hline
\end{tabular}


The American Journal of Agriculture and Boimedical Engineering (ISSN - 2689-1018)

\begin{tabular}{|c|c|c|c|}
\hline $\mathbf{2 . 7}$ & Cotesia melanoscela & $-\|-$ & $-\|-$ \\
\hline 3 & Pteromalidae family & Order of the tangenziae & Buds \\
\hline 3.1 & Callitula bicolor Spinola & $-\| /-$ & $-\|-$ \\
\hline 4 & Tachinidae family & Order of the tangenziae & Mature old worm \\
\hline $\mathbf{4 . 1}$ & Exorista larvarum L. & $-\|-$ & $-\|-$ \\
\hline $\mathbf{4 . 2}$ & Gonia bimaculata Rond. & $-\| /-$ & $-\|-$ \\
\hline
\end{tabular}

According to him, the parasite entomofag family, which effectively controls the number of Representatives of the Pieridae family in cabbage agrobiocenosis, and the species encountered in them, was considered alokhida-alokhida. According to him, 4 species from the Trichogrammatidae family (Trichogramma evanescens, Trichogramma pintoi, Trichogramma Chilonis, Trichogramma ostriniae), 7 species of the Braconidae family (Apanteles plutellae, Apanteles telengai, Apanteles Cossack, Apanteles glomeratus, Cotesia glomerata, Bracon hebetor, Cotesia melanoscela), it was found that 1 type of pteromalidae family (callitula bicolor), and 2 Type (exorista Larvarum, Gonia Bimaculata) of representatives of the tachinidae family were encountered. (Table 1).
Among these species, it became known that the 1 species of the Braconidae family (Cotesia glomerata $L$ ) is a new species for the fauna of the South East region of Uzbekistan, and these species have not been studied in depth by scientists of our country.

Based on the data presented in the literature of scientists of this species, the composition of

the species was determined in the laboratory conditions.

Representatives of this parasite entomofag family identified species of cabbage white butterfly pest but also a partial occurrence of ham in the cabbage anthill pest. 


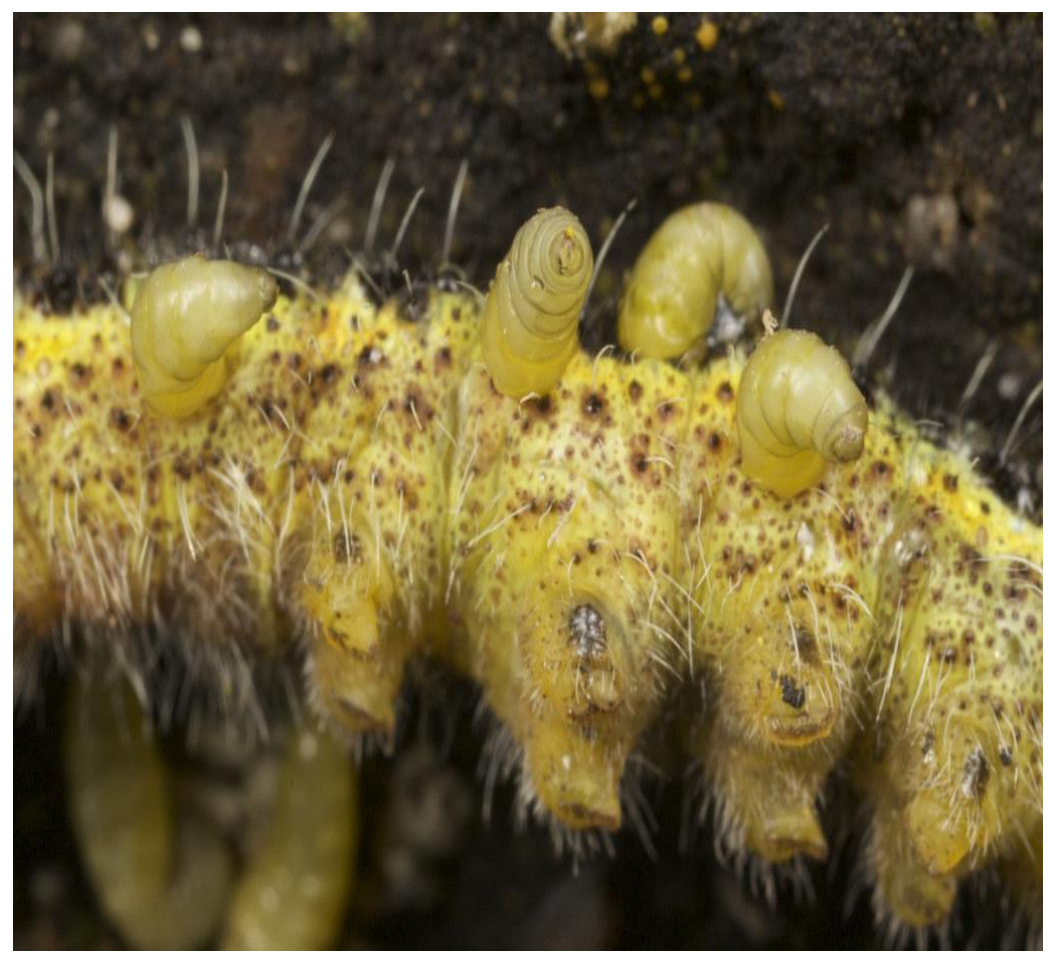

1-fig The process of the outflow of parasitic generations from the body of cabbage white butterfly infected with the Cotesia glomerata parasite and its transition to a hummock (Tashkent vil, Bekabad district; 2018-2021 yy).

The Cotesia glomerata $L$ parasite entomofag species, belonging to this Braconidae family, mainly parasitizes on the pest species Pieris brassicae, Pieris rapae and Synchlae dapicicae. Parasites were observed to lay eggs on 80 and 100 pieces on the worms of cabbage white butterflies (Figure 1).

Cabbage white butterflies qurtlari when they reach the fifth age, Cotesia ceases to develop glomerata larvae, leaving the body of the worm, and around it a lump inside the silkworm cocoons. The color of parasitic Buds is yellowish in color. The color of the parasites is black, the mustaches are long in tans, the legs are reddish(picture 1).
Thanks to the laboratory, up to 3 generations of reproduction and one female parasite were observed to cause worm damage up to 40-50 grains. The biological effectiveness achieved when used against cabbage white butterfly in agrobiocenosis of cabbage in biolaboratory reproduction parasitic genera is presented in Chapter 5.

The natural competition between seasons and years of parasitic -omoomofag species over current leadership can overwhelm most scholars, and such scientific work has not been adequately conducted by scientists of our country.

In order to expand our research, we carried out scientific work to determine the fault 
The American Journal of Agriculture and Boimedical Engineering

IMPACT FACTOR (ISSN - 2689-1018)

indicators of the degree of damage to the boss in order to study the mutual rivalry between Apanteles plutellae, Apanteles Cossack, Apanteles glomeratus, Apanteles telengai, Cotesia glomerata, Bracon hebetor parasite entomofag species in the cabbage white butterfly pest in the Tashkent region.

This scientific work was made to assess exactly which of the following types of parasites is the first pest and which type of parasite is the most important in cabbage agrobiocenosis as a result of the development of natural competition between the characteristics of this type of pest and parasitesomoomophages.

Of course, parasites-entomophages as a place of residence and nutrition in the body of pests are important in their seasonal development and adaptation to environmental factors. We conducted our research without interruption from 2017 to 2019, when barja took abiotic and biotic ome. Preliminary studies on this were carried out in 0.5 hectares of the small experimental area of Tashkent State Agrarian University and Salar Agro Fayz f/x 0.5 hectares of the Kibray District of Tashkent region in the types of duragay such as foreign Farao G'1, parel G'1, Nazomi G'1, Tashkent-10, Termez2500, kechpishar Eastiya-2. These species were sown for research.

These cabbage varieties planted seedlings of early maturing varieties 20-25 March, midmaturing varieties 1 may, late varieties 20 July, and in this period there were 5-6 leaves in the seedlings. Cabbage seedlings planted placed in the scheme of $70 \times 25(30) \mathrm{cm}$.

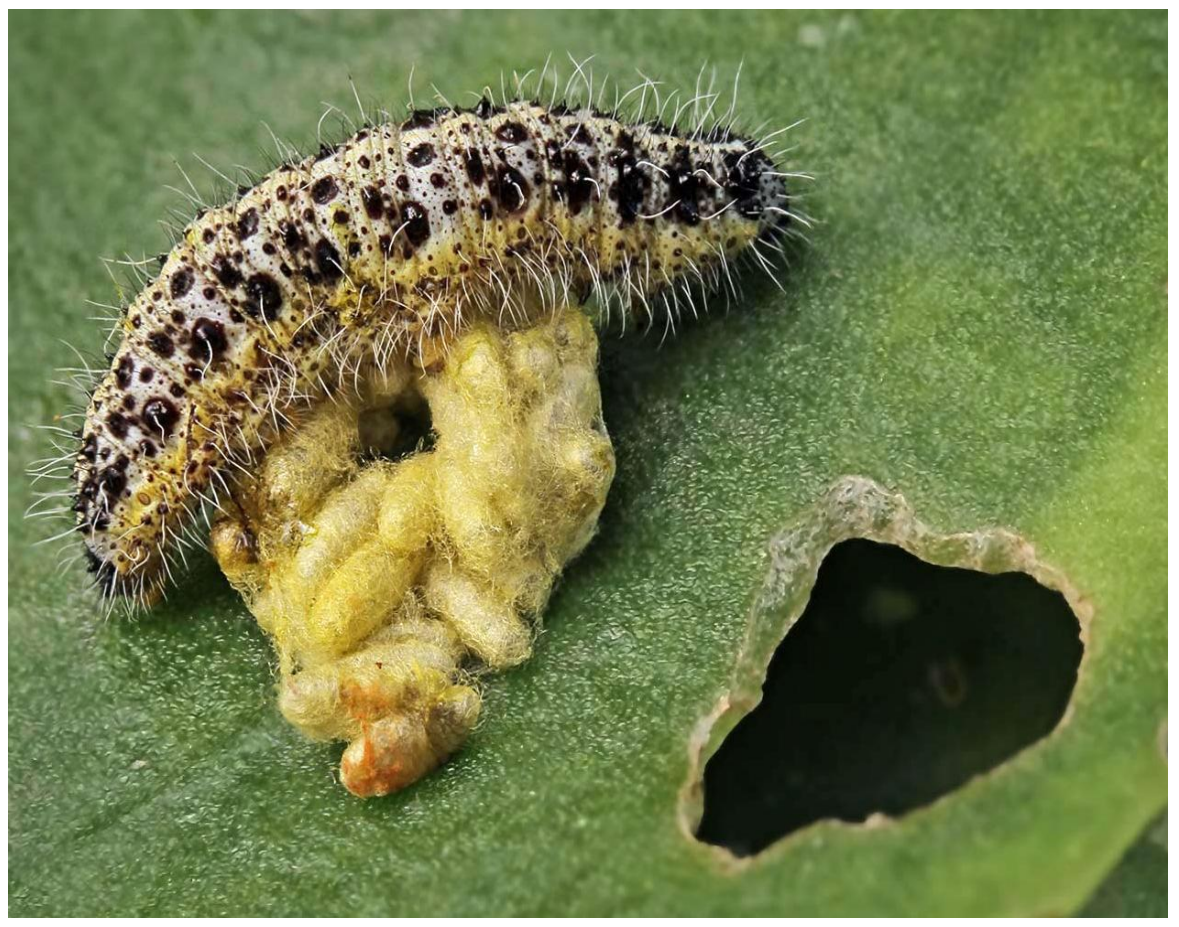

2 fig. Apanteles is a worm of cabbage white butterfly (Pieris brassicae), infected with the parasite glomeratus. (Kibray District of Tashkent region "Salar Agromaks" f/ x, 201-2021 yy). 
In the course of the research, 350 captains of the cabbage white butterfly, 814 turtles, 1600 alive, 520 killed and 1873 pieces of cabbage white butterfly in the body completely completed the stage of development, the buds of various generations of parasites, which climbed out of the body of the worm, were harvested and brought to the biolaboratorium (Figure 2).

Thanks to the laboratory, the offspring of the pest are alive fed until a certain period of time. A few scientific works on the determination of species composition of parasiticomoomophage generations brought from the field in the case of hummingbirds and parasites flying from the worms brought from the infected state and parasites brought from the infected state have been carried out by the scientific leader q.x.f.D., professor
R.A.Jumaev and b.f.D., professor X.X.Kimsanbaev and scientists of the Institute of scientific research of Zoology were carried out together.

Of the main parasites of cabbage white butterfly, which are found in cabbage agrobiocenosis, it was determined that Apanteles plutellae, Apanteles Cossack, Apanteles glomeratus, Apanteles telengai, Cotesia glomerata, Bracon hebetor species fly and their scientific studies on the study of the parasitism properties of cabbage white butterfly worms have yielded their results.

According to him, the white butterfly of cabbage (Pieris brassicae), which parasitizes most of the pest worms compared to other species, entomofag Apanteles was 35\% of the glomeratus species.

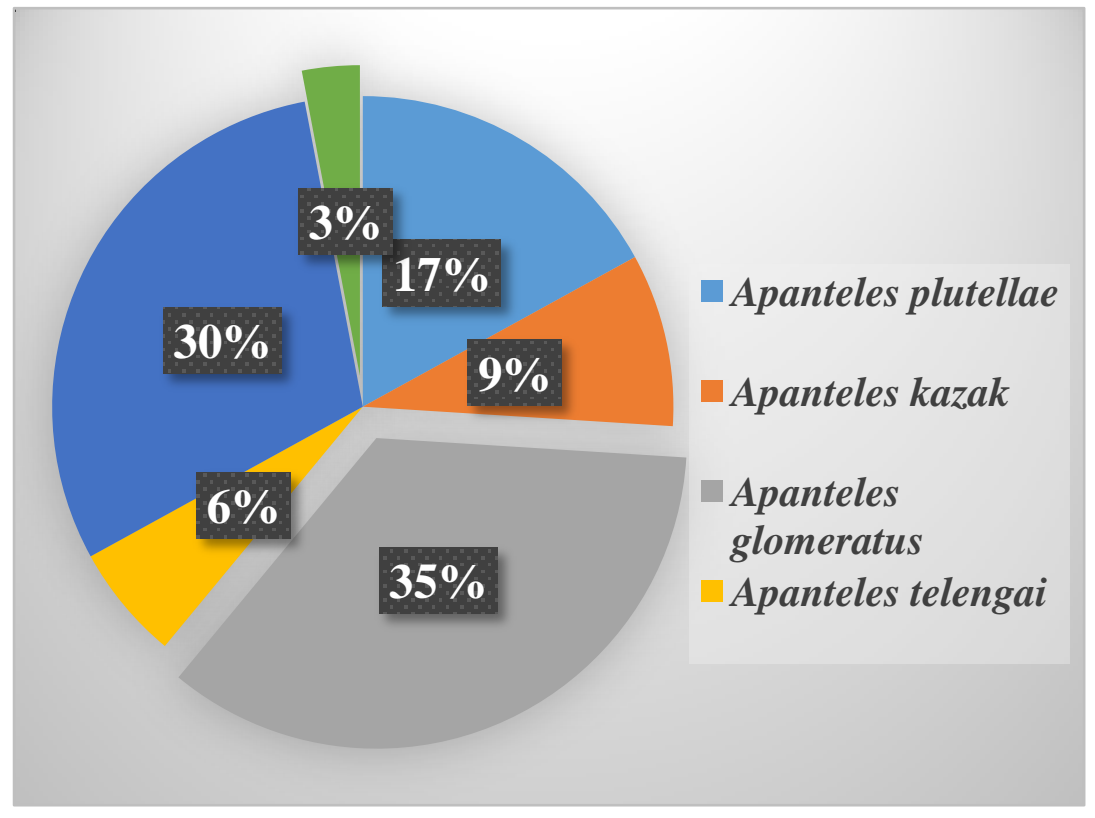

3-fig. Cabbage white cabbage in the" Tashkent-10 " Variety

levels that meet different types of parasites in their offspring. (Buka District of Tashkent region "Temur" farmer's farm, 2018-2021 yy) 
In second place, Cotesia, a new species for the fauna of the South East region of Uzbekistan, was a type of glomerata, the degree of pest infestation was 30\% compared to other species.

In third place, Apanteles was the type of plutellae $17 \%$, in fourth place Apanteles Cossack $9 \%$ in fifth place Apanteles was the type of telengai parasite entomofag 6\% (Figure 3).

The most recent, sixth place was the Bracon hebetor species parasitic entomophage, and this species was observed to infect the white cabbage butterfly only in studies conducted in the Kibray district and accounted for 3\%.

\section{CONCLUSION}

From the results of these studies it was found that Apanteles glomeratus and Cotesia glomerata species from parasitic entomophages in the effective management of the number of cabbage white butterfly yield good results. In nature, it became known that both these species had their own Sagittarius character and their leadership in relation to other species with regret. In our subsequent studies, we conducted scientific work on the reproduction of species in biolaboratorory, and in Chapter 4 of the dissertation these data are presented.

\section{REFERENCES}

1. Abbots W.S. A method of computing the effectiveness of insecticide, -1925.- V.18. №3. - P. 265-267.

2. Жумаев P.A. In vitro rearing of trichogramma (Hymenoptera: Trichogrammatidae) // European Science Review № 9-10. Austria, Vienna 2016. -Б. 1113.
3. Жумаев Р.А. Массовое размножение трихограммы на яйцах хлопковой совки в условиях биолаборатории $и$ ее применение в агробиоценозах // Халқаро илмий-амалий конфренция “Ўзбекистон мева-сабзавот махсулотларининг устунлиги" мақолалар тўплами. Тошкент:2016 -Б. 193-196.

4. Жумаев Р.А. Значение представителей семейства BRACONIDAE в регулировании численности совок в агробиоценозах // ЎзМУ Хабарлари. 2017. №3/1. -С. 67-70.

5. Жумаев Р.А., Кимсанбоев Х.Х., Адилов M.M., Рустамов A.A. The technology of rearing Braconidae in vitro in biolaboratory // European Science Review. № 3-4. Austria, Vienna 2017 -Б. 3-5.

6. Жумаев Р.А., Х.Х. Кимсанбаев.Технология размножения Bracon hebetor Say методом in vitro в биолаборатории // Актуальные вопросы современной науки. Научный журнал № 2(14) апрель 2017 -С 50-54.

7. Жумаев Р.А. Размножения ин витро Bracon hebetor Say B Bracon greeni Ashmead // Актулъные проблемы современной науки. Информационноаналитический журнал № 3(94). 2017 й. -С 215-218.

8. Кимсанбаев. Х.Х., Жумаев Р.А. Renewing and rearing technology of Bracon hebetor Say in Biolaboratory Материалы VIIIоймеждународной научно практической конфе-ренции молодых исследователей, г. Волгоград, 2014. -С. 257-260.

9. Кимсанбаев Х.Х, Сулаймонов Анарбаев А.Р., Ортиқов У.Д., Сулаймонов О.А., Жумаев Р.А., Ахмедова 3.Ю. Биоценозда ўсимлик зараркунандалари паразит энтомофагларини ривожланиши. 
«O'zbekiston» НМИУ, -Тошкент: 2016. -Б. 235.

10. Li Li-ying. In vitro rearing of parasitoids of insekt pests in China. Parasitiods and predators (insecta) of agricultural and forestry arthropod pests. Guangdong Entomological Institute. -1997. -P. 363369.

11. Li, Li-Ying. On sibling relationship among some species trichogramma. Parasitiods and predators (insecta) of agricultural and forestry arthropod pests. Guangdong Entomological Institute. -1997. -P. 22-24. 